\title{
Pengaruh In Vitro Infusa Biji Buah Pinang (Areca catechu) terhadap Tingkat Kematian dan Morfometri Ascaridia galli Dewasa
}

\author{
In Vitro Effect of Areca catechu Infusion on Mortality Rate and Morphometry \\ of Adult Ascaridia galli
}

\author{
Wida Wahidah Mubarokah ${ }^{1 *}$, Kurniasih ${ }^{2}$, Wisnu Nurcahyo ${ }^{3}$, Joko Prastowo ${ }^{3}$ \\ ${ }^{1}$ Politeknik Pembangunan Pertanian Yogyakarta Magelang, Jalan Magelang-Kopeng Km 7 Purwosari, \\ Tegalrejo, Magelang, Jawa Tengah \\ ${ }^{2}$ Departemen Patologi, Fakultas Kedokteran Hewan, Universitas Gadjah Mada, \\ Jl. Fauna 2 Karangmalang, Sleman, Yogyakarta. \\ ${ }^{3}$ Departemen Parasitologi, Fakultas Kedokteran Hewan, Universitas Gadjah Mada, \\ Jl. Fauna 2 Karangmalang, Sleman, Yogyakarta. \\ *Email: wida_wahidah02@yahoo.co.id
}

Naskah diterima: 22 Februari 2019, direvisi: 1 April 2019, disetujui: 30 November 2019

\begin{abstract}
The study evaluates in vitro effects of Areca catechu infusion as anthelmintics on mortality rate and morphometry of adult Ascaridia galli. Naturally infected chickens were collected from local chicken slaughterhouse in Yogyakarta. The intestine of chickens was carefully examined and transported to the Parasitological Laboratory, Universitas Gadjah Mada, Yogyakarta. Ascaridia galli collected from intestines (including duodenum, jejunum, and ileum) was placed in a petri dish containing $0.62 \%$ saline water. Sixty $A$. galli were placed into each concentration of Areca catechu infusion. Investigation on mortality rate of adult worms at various concentration and observation as well as differences in A. galli morphometry and mortality rate were analyzed using analysis Anova. The figures or the parts of the parasites were captured using Lucida camera and then measured using both micrometer and curvimeter. The morphology of the parasites was identified to determine the morphometric characteristics. The results of morphometric observation of the A. galli showed that there was a significant difference $(\mathrm{P}<0.05)$ in the body width and the vulva length of the females and in the body width, the esophageal length and width of the males. This research disclosed that Areca catechu crude aqueous extract significantly affected the mortality rate of adult A.galli at various concentration. This research observed the best concentration to kill adult worms is $25 \%$ of Areca catechu infusion.
\end{abstract}

Key words: Adulticidal; Areca catechu; Ascaridia galli; chicken; infusion; morphometry

\begin{abstract}
Abstrak
Penelitian ini mengevaluasi pengaruh in vitro infusa biji buah pinang (IBP) sebagai anthelmintik terhadap tingkat kematian dan morfometri Ascaridia galli dewasa. Ayam yang terinfeksi secara alami dikumpulkan dan disembelih di rumah potong ayam lokal di Yogyakarta. Usus ayam diperiksa dan dibawa ke Laboratorium Parasitologi Universitas Gadjah Mada, Yogyakarta. A. galli dikumpulkan dari usus (termasuk duodenum, jejunum, dan ileum) dan ditempatkan pada cawan petri yang berisi $\mathrm{NaCl} 0,62 \%$. Terdapat $60 \mathrm{~A}$. galli pada setiap konsentrasi IBP. Pengamatan tingkat kematian cacing dewasa pada berbagai konsentrasi dan perbedaan morfometri A. galli dianalisis menggunakan Anova. Bagian tubuh cacing digambar menggunakan kamera Lucida, kemudian diukur menggunakan mikrometer dan curvimeter. Morfologi cacing diidentifikasi untuk menemukan karakteristik morfometri. Hasil pengamatan morfometri $A$. galli menunjukkan bahwa ada perbedaan signifikan pada lebar tubuh dan panjang vulva cacing betina dan lebar tubuh, panjang serta lebar esofagus cacing jantan. Hasil penelitian ini menunjukkan bahwa IBP secara signifikan mempengaruhi tingkat kematian $A$. galli dewasa pada berbagai konsentrasi. Pada penelitian ini konsentrasi terbaik untuk membunuh cacing dewasa adalah IBP konsentrasi $25 \%$.
\end{abstract}

Kata kunci: adulticidal; Areca catechu; Ascaridia galli; ayam; infusa; morfometri 


\section{Pendahuluan}

Cacing Ascaridia galli merupakan nematode parasitik yang sering ditemukan pada unggas. Parasit tersebut menyebabkan kerugian kepada peternak berupa penurunan bobot badan dan hambatan pertumbuhan (Zalizar dan Rahayu, 2001; Zalizar et al., 2006) serta penurunan kualitas telur (Zalizar et al., 2007). Cacing selain menyerap zat-zat makanan juga menyebabkan kerusakan sel-sel epitel villi serta berkurangnya luas permukaan villi usus yang berperan dalam proses pencernaan dan penyerapan makanan (Zalizar, et al. 2006). Pemberian anthelmintik sintetik spektrum luas yang intensif dapat menimbulkan resistensi. Meningkatnya kejadian resistensi dan kesadaran konsumen yang semakin tinggi terhadap produk hewani yang bebas residu obat (Waller, 1999), menjadikan penelitian tentang anthelmintik baru merupakan pendekatan terbaik dalam mengendalikan helminthiasis. Tumbuh-tumbuhan dengan khasiat anthelmintik telah dikenal dan digunakan di beberapa negara di dunia sejak lama, akan tetapi penelitian detail untuk memvalidasi penggunaannya masih sedikit dilakukan, terutama pada kedokteran hewan (Max et al., 2002). Beberapa hasil penelitian menunjukkan bahwa tanin terkondensasi merupakan salah satu metabolit sekunder dari tumbuhan yang memiliki potensi sebagai anthelmintik. Penelitian, secara in vitro maupun in vivo telah dilakukan untuk mengetahui efek dari beberapa tumbuhan sumber tanin terhadap nematoda (Bahuaud et al., 2006).

Tumbuhan pinang di Indonesia tersebar di Pulau Sumatera, Jawa, Bali, Nusa Tenggara, Maluku dan Sulawesi. Buah pinang digunakan juga dalam dunia pengobatan yaitu mengobati penyakit seperti cacingan, perut kembung, luka, batuk berdahak, diare, kudis, koreng, terlambat haid, keputihan, beri-beri, malaria, difteri, tidak nafsu makan, sembelit, sakit pinggang, gigi dan gusi (Arisandi, 2008).

Tanin terkondensasi yang termasuk dalam golongan flavonoid pada biji pinang diduga memiliki kemampuan daya anthelmintik yang mampu menghambat enzim dan merusak membran (Shahidi dan Naczk, 1995). Terhambatnya kerja enzim dapat menyebabkan proses metabolisme pencernaan terganggu sehingga cacing akan kekurangan nutrisi pada akhirnya cacing akan mati karena kekurangan tenaga. Membran cacing yang rusak karena tanin menyebabkan cacing paralisis yang akhirnya mati.
Senyawa saponin yang terkandung dalam buah pinang akan mengiritasi membran mukosa saluran pencernaan cacing sehingga penyerapan zatzat makanan terganggu, sedangkan senyawa tanin terkondensasi pada buah pinang dapat melemaskan cacing dengan cara merusak protein kutikula tubuh cacing (Dalimartha, 2009). Alkaloid akan menghambat kerja enzim kolinesterase dalam transmisi impuls syaraf yang mempengaruhi aktifitas otot cacing Ascaridia galli sehingga terjadi depolarisasi dan kontraksi terus menerus (Sandika et al., 2012).

Berdasarkan uraian di atas diduga kuat bahwa infusa biji buah pinang (Areca catechu) memiliki kemampuan anthelmintik terhadap cacing dewasa Ascaridia galli secara in vitro. Oleh karena itu penelitian mengenai kemampuan anthelmintik tanaman herbal penting untuk dilakukan guna mengatasi resistensi dan residu terhadap obat anthelmintik kimia.

\section{Materi dan Metode}

Penelitian dilakukan di Departemen Parasitologi, Fakultas Kedokteran Hewan, Universitas Gadjah Mada.

\section{Ethical Clearance}

Penelitian disetujui oleh Komisi Ethical Clearance Laboratorium Penelitian dan Pengujian Terpadu Universitas Gadjah Mada, nomor surat 00126/04/ LPPT/XI/2018.

\section{Uji in vitro infusa biji buah pinang (IBP) terhadap Ascaridia galli}

Ascaridia galli diperoleh dari lumen usus ayam yang terinfeksi secara alami. A. galli dikumpulkan dari usus dan ditempatkan pada cawan petri yang berisi $\mathrm{NaCl}$ 0,62\%. Pada setiap konsentrasi $(10 \%, 12,5 \%$, $15 \%, 17,5 \%, 20 \%, 22,5 \%$ dan $25 \%$ ) IBP digunakan 30 ekor cacing betina dan 30 ekor cacing jantan $A$. galli. Bagian-bagian tubuh $A$. galli digambar menggunakan kamera Lucida kemudian diukur setiap bagian cacing menggunakan mikrometer dan curvimeter untuk mengetahui karakteristik morfometri A. galli.

\section{Pembuatan infusa biji buah pinang (IBP)}

Infusa biji buah pinang dipersiapkan dengan mengiris $A$. catechu menjadi irisan-irisan kecil dan kemudian dikeringkan dibawah sinar matahari. $A$. catech $u$ kering kemudian ditimbang sebanyak $10 \mathrm{~g}$ dan 
25 g lalu masing-masing ditempatkan ke dalam tabung gelas. Sebanyak $100 \mathrm{ml}$ aquadestilata ditambahkan ke dalam tabung gelas kemudian campuran dimasukkan ke dalam oven dengan temperatur $90^{\circ} \mathrm{C}$ selama 15 menit (Widiarso et al., 2018). Cairan yang tersisa disaring untuk digunakan.

\section{Analisa Data}

Tingkat kematian cacing dewasa pada berbagai konsentrasi dianalisa menggunakan analisis varians two way Anova, sementara perbedaan morfometri $A$. galli dianalisis menggunakan sidik ragam satu arah (one way Anova).

\section{Hasil dan Pembahasan}

Berdasarkan hasil analisis sidik ragam diketahui bahwa pemberian IBP secara keseluruhan mempunyai pengaruh yang signifikan terhadap tingkat kematian cacing dewasa A. galli $(\mathrm{P}<0,05)$ (Tabel 1).

Konsentrasi terbaik untuk kematian cacing dewasa terdapat pada konsentrasi $25 \%$. Konsentrasi $25 \%$ IBP mampu menyamai kemampuan membunuh cacing bila dibandingkan dengan anthelmintik kimia Pyrantel pamoat 5\% (Tabel 1).

\section{Pengaruh IBP terhadap Morfometri cacing dewasa A. galli betina dan jantan}

Hasil penelitian menunjukkan bahwa IBP memiliki pengaruh signifikan terhadap morfometri cacing $A$. galli dewasa betina dan jantan seperti ditunjukkan oleh panjang tubuh, lebar tubuh, panjang esofagus, lebar esofagus, panjang vulva, panjang preanal sucker, dan panjang spikula (Tabel 2 dan 3).

Berdasarkan Tabel 2, terdapat perbedaan signifikan pada lebar tubuh dan panjang vulva cacing

Tabel 1. Efikasi IBP terhadap tingkat kematian A. galli dewasa

\begin{tabular}{lc}
\hline \multicolumn{1}{c}{ Konsentrasi (\%) } & 6 jam \\
\hline Kontrol negatif $(\mathrm{NaCl} 0,62 \%)$ & $0,00 \pm 0,00^{\mathrm{a}}$ \\
10 & $0,00 \pm 0,00^{\mathrm{a}}$ \\
12,5 & $10,00 \pm 0,00^{\mathrm{b}}$ \\
15 & $11,70 \pm 1,65^{\mathrm{b}}$ \\
17,5 & $11,70 \pm 0,00^{\mathrm{b}}$ \\
20 & $33,00 \pm 7,85^{\mathrm{c}}$ \\
22,5 & $50,00 \pm 9,30^{\mathrm{d}}$ \\
25 & $100,00 \pm 0,00^{\mathrm{e}}$ \\
Pyrantel pamoat $5 \%$ & $100,00 \pm 0,00^{\mathrm{e}}$ \\
\hline
\end{tabular}

a,b,c,d,e Superskrip yang berbeda dalam satu kolom yang sama menunjukkan adanya perbedaan signifikan $(\mathrm{P}<0,05)$
A. galli betina pada konsentrasi $25 \%, 10 \%$ dan $0 \%$ $(\mathrm{P}<0,05)$. Tidak ada perbedaan lebar tubuh yang signifikan di antara konsentrasi 10\% dan $0 \%$ (kontrol), tetapi ada perbedaan signifikan di antara konsentrasi $25 \%$ dan $0 \%(\mathrm{P}<0,05)$. Tidak ada perbedaan signifikan pada panjang vulva di konsentrasi $10 \%$ dan $0 \%$, tetapi ada perbedaan signifikan antara konsentrasi $25 \%$ dan $0 \%(\mathrm{P}<0,05)$. Tidak ada perbedaan signifikan pada panjang tubuh, panjang dan lebar esophagus di IBP konsentrasi $10 \%$ dan $25 \%$. Kerusakan kutikula yang disebabkan oleh tanin yang terkandung di dalam IBP dapat menurunkan lebar tubuh dan panjang vulva $A$. galli betina.

Cacing A. galli dewasa jantan memiliki perbedaan signifikan pada panjang tubuh, lebar tubuh, panjang esofagus dan lebar esofagus $(\mathrm{P}<0,05)$. IBP pada konsentrasi $10 \%$ dan $25 \%$ mampu menurunkan lebar tubuh dan lebar esofagus pada cacing jantan (Tabel 3). Hasil pengamatan mikroskopik morfometri A. galli menunjukkan bahwa ada perbedaan signifikan $(\mathrm{P}<0,05)$ pada panjang tubuh, lebar tubuh, panjang esofagus, dan lebar esofagus cacing jantan (Tabel 3). IBP pada konsentrasi 25\% dapat menurunkan panjang tubuh cacing dewasa jantan. Namun demikian, tidak ada perbedaan signifikan di dalam panjang tubuh di antara IBP konsentrasi $10 \%$ dan $0 \%$. IBP pada konsentrasi $10 \%$ dan $25 \%$ menyebabkan penurunan lebar tubuh cacing. Ada perbedaan signifikan di antara konsentrasi-konsentrasi IBP, baik 10\%, 25\%, dan $0 \%$. Perbedaan signifikan $(\mathrm{P}<0,05)$ terlihat pada panjang esofagus, antara konsentrasi IBP 25\% $(3,37 \pm 0,26)$ dan $0 \%(3,66 \pm 0,41)$, tetapi tidak ada perbedaan signifikan pada panjang esofagus di antara konsentrasi $25 \%$ $(3,37 \pm 0,26)$ dan $10 \%(3,51 \pm 0,32)$. Tidak ada perbedaan signifikan pada panjang spikula cacing yang terpapar

Tabel 2. Morfometri cacing A. galli dewasa betina yang dipapar IBP secara in vitro.

\begin{tabular}{|c|c|c|c|}
\hline $\begin{array}{l}\text { Morfometri } \\
\text { A.galli }\end{array}$ & $\begin{array}{c}\text { Kontrol } \\
(0 \%)\end{array}$ & $\begin{array}{l}\text { IBP } 10 \% \\
(\mathrm{~mm})\end{array}$ & $\begin{array}{l}\text { IBP } 25 \% \\
\text { (mm) }\end{array}$ \\
\hline Panjang tubuh & $8,59 \pm 0,88^{a}$ & $8,47 \pm 0,90^{\mathrm{a}}$ & $8,17 \pm 0,59^{a}$ \\
\hline Lebar tubuh & $0,98 \pm 0,07^{\mathrm{a}}$ & $0,97 \pm 0,06^{\mathrm{a}}$ & $0,93 \pm 0,06^{\mathrm{b}}$ \\
\hline $\begin{array}{l}\text { Panjang } \\
\text { Esofagus }\end{array}$ & $3,30 \pm 0,31^{\mathrm{a}}$ & $3,24 \pm 0,30^{\mathrm{a}}$ & $3,16 \pm 0,29^{a}$ \\
\hline Lebar esofagus & $0,43 \pm 0,04^{\mathrm{a}}$ & $0,41 \pm 0,05^{\mathrm{a}}$ & $0,39 \pm 0,05^{\mathrm{a}}$ \\
\hline Panjang vulva & $4,67 \pm 0,31^{\mathrm{a}}$ & $4,12 \pm 0,22^{\mathrm{a}}$ & $3,87 \pm 0,67^{\mathrm{b}}$ \\
\hline
\end{tabular}

a,b Superskrip yang berbeda dalam baris yang sama menunjukkan perbedaan yang signifikan $(\mathrm{P}<0,05)$. Jumlah cacing yang diukur untuk setiap konsentrasi adalah 60 (30 jantan dan 30 betina), $A$. galli $=$ Ascaridia galli, A.catech $u=$ Areca catech $u$, IBP $=$ Infusa Biji Buah Pinang (Areca catechu) 
pada konsentrasi $10 \%$ dan $0 \%$. Sementara itu, terdapat perbedaan signifikan $(\mathrm{P}<0,05)$ di dalam lebar esofagus A. galli jantan pada konsentrasi $25 \%(0,42 \pm 0,07)$ dan $10 \%(0,46 \pm 0,08)$, juga pada konsentrasi $25 \%$ dan $0 \%$ $(0,48 \pm 0,08)$. A. galli yang direndam di dalam IBP pada konsentrasi $10 \%$ menunjukkan tidak semua cacing mati namun semua cacing mati pada konsentrasi $25 \%$. Perbedaan morfometri di antara beberapa konsentrasi dan kontrol mungkin berhubungan dengan pengaruh kandungan fitokimia IBP yang bisa merusak kutikula cacing dewasa.

Pada penelitian ini menunjukkan IBP dengan konsentrasi 25\% mempunyai efek daya anthelmintik terbesar terhadap cacing A. galli (Tabel 2 dan 3), hal tersebut sesuai dengan penelitian yang dilakukan oleh Tiwow et al. (2013) yang menyatakan bahwa pada konsentrasi 20\% ekstrak etanol biji pinang secara in vitro mampu membuat cacing $A$. galli menjadi lisis atau mati, sedangkan konsentrasi 30\% memiliki daya anthelmintik lebih efektif terhadap cacing $A$. galli.

Hasil penelitian menunjukkan bahwa A. galli pada kelompok kontrol memiliki karakteristik morfologis sama seperti yang ditemukan oleh Ramadhan dan Znada (1992), termasuk warna, panjang tubuh, lebar tubuh, panjang esofagus, lebar esofagus, panjang vulva, panjang preanal sucker, dan panjang spikula.

Pemeriksaan fitokimiawi awal terhadap A. catechu menunjukkan bahwa $A$. catechu mengandung flavonoid, tanin, saponin, monoterpene, sesquiterpene, phenol, quinone dan alkoloid (arecoline dan arecaine) (Amudhan et al., 2012). Tanin bisa mempengaruhi cacing-cacing dewasa baik secara langsung maupun secara tidak langsung. Reaksi langsung terjadi ketika tanin melekat pada kutikula cacing (Zhong et

Tabel 3. Morfometri cacing A. galli dewasa jantan yang dipapar IBP secara in vitro.

\begin{tabular}{lccc}
\hline $\begin{array}{l}\text { Morfometri } \\
\text { A.galli }\end{array}$ & kontrol $(0 \%)$ & $\begin{array}{c}\text { IBP 10\% } \\
(\mathrm{mm})\end{array}$ & $\begin{array}{c}\text { IBP 25\% } \\
(\mathrm{mm})\end{array}$ \\
\hline Panjang tubuh & $6,29 \pm 0,67^{\mathrm{a}}$ & $6,20 \pm 0,54^{\mathrm{a}}$ & $5,76 \pm 0,57^{\mathrm{b}}$ \\
Lebar tubuh & $0,80 \pm 0,57^{\mathrm{a}}$ & $0,79 \pm 0,45^{\mathrm{b}}$ & $0,76 \pm 0,07^{\mathrm{c}}$ \\
Panjang esofagus & $3,66 \pm 0,41^{\mathrm{a}}$ & $3,51 \pm 0,32^{\mathrm{a}}$ & $3,37 \pm 0,26^{\mathrm{b}}$ \\
Lebar esofagus & $0,48 \pm 0,08^{\mathrm{a}}$ & $0,46 \pm 0,08^{\mathrm{b}}$ & $0,42 \pm 0,07^{\mathrm{c}}$ \\
Panjang preanal & $0,20 \pm 0,00^{\mathrm{a}}$ & $0,21 \pm 0,03^{\mathrm{a}}$ & $0,20 \pm 0,04^{\mathrm{a}}$ \\
sucker & $2,07 \pm 0,45^{\mathrm{a}}$ & $2,00 \pm 0,42^{\mathrm{a}}$ & $1,91 \pm 0,36^{\mathrm{a}}$ \\
\hline
\end{tabular}

a,b,c Superskrip yang berbeda dalam baris yang sama menunjukkan perbedaan yang signifikan $(\mathrm{P}<0,05)$. Jumlah cacing yang diukur untuk setiap konsentrasi adalah 60 ( 30 jantan dan 30 betina), A.galli $=$ Ascaridia galli, A catech $u=$ Areca catech $u$, IBP $=$ Infusa Biji Buah Pinang(Areca catechu). al., 2014). Kutikula nematoda diketahui memiliki banyak peran penting dalam menjalankan fungsi penyerapan, perlindungan dan selektif. Lebih jauh, kutikula nematoda menjadi tempat yang menjadi sasaran utama obat-obat anthelmintik (Alvarez et al., 2007). Lalchhandama et al., (2009) menyatakan bahwa cacing $A$. galli dewasa yang diberi perlakuan dengan albendazole mengalami penghancuran kutikula. Anthelmintik juga menyebabkan goresan-goresan melintang sepanjang badan kutikula $W$. Bancrofti (Oliveira et al., 2007). Sebelumnya, Robinson et al., (2004) menjelaskan bahwa albendazole memiliki pengaruh penghentian polimerisasi $\beta$-tubulin mikrotubula dan ini menyebabkan kerusakan struktural dan fungsional pada parasit. Hal ini sama dengan temuan Roy et al., (2012). Jadi, tampak jelas bahwa pengaruh ekstrak A. oxyphylla menyebabkan kerusakan epikutikula dan juga kutikula cacing A. galli dewasa. Penelitian lain melaporkan bahwa pengaruh ekstrak Calendula micrantha menyebabkan permukaan mengkerut dengan menghilangnya goresan-goresan sepanjang tubuh kutikula cacing A. galli (Hassain et al., 2009). Pengaruh senyawa aktif yang diisolasi dari $A$. oxyphylla terhadap nematoda menyebabkan kerusakan pada permukaan tubuh A. galli (Roy et al., 2012).

Hasil yang sama juga menunjukkan bahwa tanin dapat merusak kutikula Haemonchus contortus. Perubahan pada kutikula $H$. contortus dengan kerutankerutan membujur dan melintang setelah pemaparan in vitro terhadap Biophytum persianum yang kaya akan tanin dievaluasi oleh Sambodo et al., (2018). Kerutankerutan pada kutikula $H$. contortus juga diamati oleh Martinez et al., (2013). Pada cacing dewasa kutikula berperan pada motilitas dan pertukaran dengan lingkungan parasit, termasuk pertukaran metabolik dengan lingkungan lokal di dalam saluran pencernaan hospes (Martinez et al., 2013). Penurunan panjang dan lebar tubuh yang disebabkan oleh tanin terjadi pada Haemonchus contortus (Kuchai et al., 2012).

Mekanisme unsur-unsur pokok fitokimia yang bekerja membasmi parasit bisa menunjukkan cara-cara yang berbeda. Lorent et al., (2014) menjelaskan bahwa aktivitas sitotoksik saponin yang membentuk pori-pori pada membran sel bisa mengganggu keseimbangan ion sel itu yang berakibat pada lisis dan kematian sel. Mekanisme alkoloid yang diekstraksi dari Combretum zeyheri menurut Nyambuya et al., (2017), mungkin berhubungan dengan penghambatan membranmembran sel. Secara umum, mekanisme aktivitas 
anthelmintik ekstrak berbasis tanaman bisa bekerja ketika ekstrak ini mempengaruhi dan menggabungkan membran-membran sel untuk memunculkan perubahan pada komposisi sel. Akibatnya, perubahan komposisi sel ini memunculkan destabilisasi membran, perubahan kekuatan membran, dan kehilangan potensi membran yang menyebabkan lisis sel, yang selanjutnya merusak kutikula dan menyebabkan penurunan secara morfometri.

\section{Kesimpulan}

Infusa biji buah pinang secara signifikan mempengaruhi tingkat kematian $A$. galli dewasa pada berbagai dosis dan waktu pengamatan. Konsentrasi terbaik untuk membunuh cacing dewasa adalah IBP konsentrasi 25\%. Pengamatan secara morfometri $A$. galli menunjukkan bahwa ada perbedaan signifikan pada lebar tubuh dan panjang vulva cacing betina dan lebar tubuh, panjang esofagus serta lebar esofagus cacing jantan.

\section{Daftar Pustaka}

Alvarez, L.I., Mottier, M.L. and Lanusse, C.E. (2007). Drug Transfer into Target Helminths Parasites. Trends Parasitol., 23: 97-104.

Amudhan, M.S., Begum, V.H. and Hebbar, K.B. (2012). A Review on Phytochemical and Pharmacological Potential of Areca catechu L. seed. Int. J. Pharm. Sci. Res., 3: 4151-4157.

Arisandi, Y. (2008). Khasiat Tanaman Obat. Jakarta: Pustaka Buku Merah

Bahuaud, D., Martinez-Ortiz de Montellano, C., Chauveau, S., Prevot, F., Torres-Acosta, F., Fouraste, I., and Hoste, H. (2006). Effects of Four Tanniferous Plant Extracts on the in Vitro Exsheathment of Third-Stage Larvae of Parasitic Nematodes. Parasitology. 132:545-54.

Dalimartha, S. (2009). Atlas Tumbuhan Obat Indonesia. Jakarta. Penebar Swadaya.

Hassanain, M.A., Rahman, E.H.A. and Khalil, F.A.M. (2009). New Scanning Electron Microscopy Look of Ascaridia galli (Schrank 1788) Adult Worm and Its Biological Control. Res. J. Parasitol., 4: 1-11.

Kuchai, J.A., Ahmad, F., Chishti, M.Z., Tak, H., Ahmad, J.A.S. and Razool, M. (2012). A
Study on Morphology and Morphometry of Haemonchus contortus. Pak. J. Zool., 44(6): 1737-1741.

Lalchhandama, K., Roy, B. and Dutta, B.K. (2009). Anthelmintic Activity of Acacia oxyphylla Stem Bark Against Ascaridia galli. Pharm. Biol., 47(7): 578-583.

Lorent, J.H., Quetin-Leclercq, J. and MingeotLeclercq, M.P. (2014). The Amphiphilic Nature of Saponins and Their Effects an Artificial and Biological Membranes and Potential Consequences for Red Blood and Cancer Cells. Org. Biomol. Chem., 12: 8803-8822.

Martinez-Ortiz-de-Montellano, C., Arroyo-Lopez, C., Fourquaux, I., Torres-Acosta, J.F.J., SandovalCastro, C.A. and Hoste, H. (2013). Scanning Electron Microscopy of Haemonchus contortus Exposed to Tannin-Rich Plants Under In Vivo And In Vitro Conditions. Exp. Parasitol., 133(3): 281-286.

Max, R.A., Dawson, J.M., Wakelin, D., Buttery, P.J., Kimambo, A.E., Kassuku, A.A. and Mtenga, L.A. (2002). Effect of Condensed Tannin Extracts on Gastrointestinal Nematodes of Small Ruminants. In: Proceedings of the Second DFID Livestock Production Programme Link Project (R7798) Workshop for Smallstock Holders. Sokoine University of Agriculture, Morogoro, Tanzania

Nyambuya, T., Mautsa, R. and Mukanganyama, S. (2017). Alkaloid Extracts from Combretum zeyheri Inhibit the Growth of Mycobacterium smegmatis. BMC Compl. Altern. Med., 17(124): $1-11$.

Oliveira-Menezes, A., Lins, R., Norões, J., Dreyer, G. and Lanfredi, R.M. (2007). Comparative Analysis of a Chemotherapy Effect on The Cuticular Surface of Wuchereria bancrofti Adult Worms In Vivo. Parasitol. Res., 101: 1311-1317.

Ramadan, H. H. and Znada, N. Y. A. (1992). Morphologi and Life History of Ascaridia galli in the Domestic Fowl That are Raised in Jeddah. J.K.A.U.Sci., 4: 87- 99.

Robinson, M.W., McFerran, N., Trudgent, A., Hoey, L. and Fairweather, I. (2004). A Possible Model of Benzimidazole Binding to $ß$-Tubulin Disclosed 
by Invoking an Inter-Domain Movement. $J$. Mol. Graph. Model., 23: 275-284.

Roy, B., Dasgupta, S., Manivel, V., Parameswaran, P.S. and Giri, B.R. (2012). Surface Topographical and Ultrastructural Alterations of Raillietina Echinobothrida and Ascaridia Galli Induced by a Compound Isolated from Acacia oxyphylla. Vet. Parasitol., 185: 322-326.

Sambodo, P., Prastowo, J., Kurniasih, K. and Indarjulianto, S. (2018). In vitro Potential Anthelmintic Activity of Biophytum petersianum on Haemonchus contortus. Vet. World., 11(1): 1-4.

Sandika, B., Raharjo, and Ducha, N. (2012). Pengaruh Pemberian Air Rebusan Akar Delima (Punica granatum L) Terhadap Mortalitas Ascaris suum. Goesze. Secara In Vitro. Lentera Bio, 1:81-86.

Shahidi, F and M. Naczk. (1995). Food Phenolics. Technomic Inc, Basel. p.481-482

Tiwow, D., Bodhi W. and Kojong, N.S. (2013). Uji Efek Anthelmintik Ekstrak Etanol Biji Pinang (Areca catechu) Terhadap Ascaris lumbricoides dan Ascaridia galli Secara In Vitro. Pharmacon, 76-80.

Waller, P.J. (1999). International Approaches to the Concept of Integrated Control of Nematode Parasites of Livestock. Int. J. Parasitol. 29,155164.
Widiarso, B.P., Kurniasih, K., Prastowo, J., and Nurcahyo, W. (2018). Morphology and Morphometry of Haemonchus contortus Exposed to Gigantochloa apus Crude Aqueous Extract. Vet. World., 11(7): 921-925.

Zalizar L, and Rahayu I.D. (2001). Pengaruh Penggunaan Larutan Bawang Putih Terhadap Penampilan Produksi Ayam Lurik Penderita Parasit Cacing. Jurnal Agritek, 9:2.

Zalizar L, Satrija F, Tiuria R, and Astuti DA. (2006). Dampak Infeksi Ascaridia galli Terhadap Gambaran Histopatologi dan Luas Permukaan Vili Usus Serta Penurunan Bobot Hidup Starter. Jurnal Ilmu Ternak dan Veteriner 11(3): 215222.

Zalizar L, Fadjar. S, Risa. T, and Dewi AA. (2007). Respon Ayam yang Mempunyai Pengalaman Infeksi Ascaridia Galli Terhadap Infeksi Ulang Dan Implikasinya Terhadap Produktivitas dan Kualitas Telur. Animal Production. Jurnal Produksi Ternak 9(2): 92-98.

Zhong, R.Z., Sun, H.X., Liu, H.W. and Zhou, D.W. (2014). Effects of Tannin Acid on Haemonchus contortus Larvae Viability and Immune Responses of Sheep White Blood Cells In Vitro. Parasite Immunol., 36: 100-106. 